\title{
Studies on Biochemical Changes and Changes in Cell Wall Degrading Enzymes in Papaya Fruit Inoculated with Colletotrichum demetium
}

\author{
H.N. Prajapati*, R.K. Patil and Y.M. Shukla \\ Horticulture College, B. A. College of Agriculture, Anand Agricultural University, \\ Anand-388110, Gujarat, India \\ *Corresponding author
}

\begin{tabular}{|c|c|}
\hline & A B S T R A C T \\
\hline & \multirow{8}{*}{$\begin{array}{l}\text { Studies on biochemical changes (soluble sugar, phenol, protein, ash, phosphorus, calcium) } \\
\text { and changes in cell wall degrading enzymes (PG, PMG and CX) in papaya fruit inoculated } \\
\text { with Colletotrichum demetium was carried out. Total protein content of inoculated papaya } \\
\text { fruits was decreased by } 0.63,0.58 \text { and } 0.36 \text { per cent at } 6^{\text {th }}, 7^{\text {th }} \text { and } 8^{\text {th }} \text { day after inoculation, } \\
\text { respectively, while in control fruit protein content was } 1.80 \mathrm{mg} / \mathrm{g} \text {. The TSS content in } \\
\text { inoculated papaya fruits is progressively decreased by } 3.93,3.71 \text { and } 3.42 \text { per cent at } 6^{\text {th }} \text {, } \\
7^{\text {th }} \text { and } 8^{\text {th }} \text { day after inoculation. The total phenol content in papaya fruits inoculated with } \\
\text { C. dematium were appreciably increased up to } 3^{\text {rd }} \text { day and after that there was gradual } \\
\text { decline in phenol content observed. Ash content in inoculated fruits was decreased } \\
\text { progressively as the duration after inoculation increased after } 6^{\text {th }}, 7^{\text {th }} \text { and } 8^{\text {th }} \text { day of } \\
\text { inoculation, respectively. Calcium content was gradually reduced after inoculation as there } \\
\text { was an increase in incubation period. Significantly lowest calcium content was recorded on } \\
8^{\text {th }} \text { day after inoculation }(12.17 \mathrm{mg} / 100 \mathrm{ml}) \text {. The phosphorous content decreased by } 7.73 \text {, } \\
5.17 \text { and } 3.53 \mathrm{mg} / 100 \mathrm{ml} \text { at } 6^{\text {th }}, 7^{\text {th }} \text { and } 8^{\text {th }} \text { day after inoculation, respectively. The } \\
\text { enzymatic activities of PG, PMG and CX were higher in ripe fruits as compare to semi ripe } \\
\text { fruits, respectively. }\end{array}$} \\
\hline & \\
\hline $\begin{array}{l}\text { Colletotrichum } \\
\text { demetium, Poly }\end{array}$ & \\
\hline $\begin{array}{l}\text { ethylene glycol, } \\
\text { C. gloeosporioides }\end{array}$ & \\
\hline Article Info & \\
\hline $\begin{array}{l}\text { Accepted: } \\
\text { 21 June } 2017\end{array}$ & \\
\hline $\begin{array}{l}\text { Available Online: } \\
\text { 10 July } 2017\end{array}$ & \\
\hline & \\
\hline
\end{tabular}

\section{Introduction}

The papaya is the fruit of the plant Carica papaya L., the sole species in the genus Carica of the family Caricaceae. It is native of tropical America. It was first cultivated in Mexico. Papaya is called as "common mans" fruit which is due to reasonable price and has a high nutritive value. It is low in calories and rich in natural vitamins and minerals. Papaya place first among the fruits for vitamin $\mathrm{C}$ and A, riboflavin, folate calcium, thiamine, iron, pantothenic acid, niacin, potassium and fibre. The comparative low calories content (32 $\mathrm{Kcal} / 100 \mathrm{gm}$ of ripe fruits) make this favourite fruit of obese people who are into weight reducing regime (Krishna et al., 2008; Thamaraikannan and Sengottuvel, 2012).

Papaya is prone to many diseases incited by fungi, bacteria, nematodes and viruses leading to enormous loss in yield. Among all, papaya anthracnose incited by Colletotrichum gloeosporioides (Penz.) Penz. and Sacc. appears to be more severe causing substantial losses to papaya fruits during transit and storage. 


\section{Materials and Methods}

\section{Estimation of total protein, total sugar and total phenol, calcium and phosphorous from infected and healthy tissues}

\section{Total protein content}

Protein content was determined by the method developed by Lowry et al., (1951). Take $1 \mathrm{~g}$ of sample and homogenized in five $\mathrm{ml} \quad 0.1 \mathrm{~N} \mathrm{NaOH}$ and filtered through Whatman No.1 filter paper. The sample extracts $1 \mathrm{ml}$ was taken and made to $10 \mathrm{ml}$ volume with distilled water. $5 \mathrm{ml}$ of alkaline copper solution $\left(50 \mathrm{ml} 2 \% \mathrm{Na}_{2} \mathrm{CO}_{3}\right.$ in $0.1 \mathrm{~N}$ $\mathrm{NaOH}+1 \mathrm{ml} 0.5 \% \mathrm{CuSO}_{4}$ in $10 \%$ Sodium Potassium tartrate) was added. The content was allowed to stand for 10 minutes at room temperature followed by addition of $0.5 \mathrm{ml}$ solution Folin Ciocalteu reagent $(1: 1 \mathrm{v} / \mathrm{v})$. The content was kept for 30 minutes at room temperature and the absorbance was measured at $750 \mathrm{~nm}$. The protein content was calculated using bovine serum albumin as standard range from $50-300 \mu \mathrm{g}$.

True protein $(\%)=$ Graph factor $\frac{\text { Sample reading }}{\text { weight of sample }} \times \frac{\text { Total volume }}{\text { Taken volume }} \times 10^{-4}$

\section{Total soluble sugar content}

Total soluble sugar from the semi-ripe papaya pulp both inoculated with pathogen and uninoculated was determined by phenol sulphuric acid method as described by Dubois et al., (1956). One gram of pulp sample was macerated in $5 \mathrm{ml} \mathrm{80 \%} \mathrm{alcohol} \mathrm{and} \mathrm{taken} \mathrm{in}$ $30 \mathrm{ml}$ sugar test tubes and total volume was made to $10 \mathrm{ml}$ with $80 \%$ alcohol. The test tubes were kept overnight. Next day take one $\mathrm{ml}$ supernatant from each test tube and was evaporated to dryness in water bath. After evaporation make the volume to $25 \mathrm{ml}$ with distilled water in beaker. From this $25 \mathrm{ml}$, one $\mathrm{ml}$ test solution was used for assay in which freshly prepared $1 \mathrm{ml} 5$ per cent phenol solution was added followed by immediate direct addition of $5 \mathrm{ml}$ concentrated sulphuric acid solution. The tubes were kept for $10 \mathrm{~min}$. at room temperature for colour development. After mixing the solution it was kept for further $15 \mathrm{~min}$. in cold water bath. The intensity of stable yellow colour developed was recorded at O.D. $490 \mathrm{~nm}$ in spectrophotometer. In a similar way take 0.2 , $0.4,0.6,0.8$ and $1.0 \mathrm{ml}$ of the working standard glucose solution having 10 to $50 \mu \mathrm{g}$ glucose, was pipetted out into a series of test tubes. The volume of each test tube was made up to $1 \mathrm{ml}$ with distilled water. For blank, one $\mathrm{ml}$ of distilled water was taken. Sugar content was determined by using the following formula:

Total soluble sugar $(\mathrm{g} / 100 \mathrm{~g})=$ Sample O.D x Graph factor (mg sugar) x 250/1000

\section{Total phenol content}

Total phenol content from the semi-ripe papaya pulp both inoculated and uninoculated was estimated by Folin ciocalteau method as described by Bray and Thorpe (1954) with some modification. Take $1 \mathrm{~g}$ sample of papaya tissue and homogenized in 80\% methanol using mortar and pestle and final volume was made to $10 \mathrm{ml}$. The content was refluxed for two hour on boiling water bath at $65^{\circ} \mathrm{C}$. Supernatant was collected and residue was reextracted twice with 80\% methanol. All supernatant were combined and final volume was made to $25 \mathrm{ml}$. The extract was used for the assay of total phenol. Total phenol was estimated by following the method of Bray and Thorpe (1954) with some modifications. Aliquot $0.5 \mathrm{ml}$ was taken and made the final volume $1.0 \mathrm{ml}$ with distilled water. To this add $0.5 \mathrm{ml}$ of Folin-Ciocalteu reagent and after $3 \mathrm{~min} 2 \mathrm{ml}$ of $20 \% \mathrm{Na}_{2} \mathrm{CO}_{3}$ was added and the tubes were incubated in boiling water 
bath for 1 min., cooled it, and made total volume $10 \mathrm{ml}$ with distilled water. The absorbance was measured at $650 \mathrm{~nm}$. Phenol content was calculated from the standard curve prepared from Catechol.

Total Phenols $(\%)=$ Graph factorx $\frac{\text { Sample reading }}{\text { weightof sample }} \times \frac{\text { Total volume }}{\text { Taken volume }} \times 10^{-4}$

\section{Estimation of calcium}

\section{Estimation of ash}

2 gm of fruit pulp was placed in a previously weighed crucible and it was subjected for heating on hot plate till the sample was sufficiently turned black about 30 minutes. Then it was placed in muffle furnace, preheated to $600^{\circ} \mathrm{C}$ for 2 hours with automatic control. Crucible were transferred directly to desiccators, cooled and weighed immediately. Weigh of ash was obtained per $2 \mathrm{gm}$ of sample and further calculated the ash content. An aliquot $(25 \mathrm{ml})$ of the acid solution ash portion was diluted to about $150 \mathrm{ml}$ with distilled water. Few drops of methyl red are added and the mixture is neutralized with ammonia $\left(\mathrm{NH}_{3}\right)$ solution till the pink colour changes to yellow. The solution was heated to boiling and the $10 \mathrm{ml}$ ammonium oxalate solution was added.

The mixture was allowed to boil for a few minutes. Glacial acetic acid was then added till distinctly pink colour reappeared. The mixture was then kept aside for 12 to 24 hours at room temperature. When the precipitate at calcium oxalate settles down, it was filtered through Whatman's filter paper No.42. The precipitate was washed several times with distilled water, to make it free from acid. It was then transferred in a small beaker by piercing a hole in the filter paper and by pouring over it about $15 \mathrm{ml} 2 \mathrm{~N} \mathrm{H}_{2} \mathrm{SO}_{4}$. This is heated to above $40^{\circ} \mathrm{C}$ and titrated against $0.01 \mathrm{~N} \mathrm{KMNO}_{4}$ solution until the first drop which gives the solution a pink colouration persisting for at least 30 second. The amount of calcium was calculated using an equation. $1 \mathrm{ml}$ of $\mathrm{KMNO}_{4}=0.2004 \mathrm{mg}$ of $\mathrm{Ca}$. The percent $\mathrm{Ca}$ on dry Matter basis was then calculated on the basis of the amount of sample used for ashing, the volume to which acid solution of ash is diluted and the volume of the aliquot taken for the precipitation of calcium.

\section{Estimation of phosphorous}

$0.5 \mathrm{ml}$ of acid soluble portion of ash was taken in a test tube and diluted it to a volume of $10 \mathrm{ml}$ with distilled water. Simultaneously a blank containing only $10 \mathrm{ml}$ distilled water was taken and $1 \mathrm{ml}$ molybdate solution was added to each test tube and mix, and then 0.4 ml ANSA reagent (In a $100-\mathrm{mL}$ volumetric flask dissolve $2.0 \mathrm{~g}$ sodium sulphite $\left(\mathrm{Na}_{2} \mathrm{SO}_{3}\right)$ in approximately $80 \mathrm{~mL}$ of reagent water. Add $0.25 \mathrm{~g}$ of 1-amino-2-napthol-4sulfonic acid) was added and again mixes. Allowed to stand for 5 minutes and noted/observed the optical density (O.D.) at $660 \mathrm{~nm}$ using colorimeter by setting it to a zero with the blank.

\section{Estimation of cell wall degrading enzymes on disease development}

Semi-ripe were surface sterilized and separately inoculated with Colletotrichum dematium by pin-prick method. The inoculated fruits were incubated at ambient temperature. On $1^{\text {st }}, 2^{\text {nd }}, 3^{\text {rd }}$ and $4^{\text {th }}$ day, extracts from semi-ripe and ripe fruits were obtained according to the procedure described by Bell et al., (1955). Five grams of the rotted and healthy fruit tissues were macerated separately with the help of a pestle and mortar in distilled water $(15 \mathrm{ml})$ and $0.5 \mathrm{~N} \mathrm{NaCl}(15$ $\mathrm{ml})$. The ground tissues extract were strained through several layers of cheese cloth. The filtrates from semi-ripe and ripe fruits were 
separately centrifuged at $4000 \mathrm{rpm}$ for 20 min. The supernatant were used for cell wall degrading enzyme study. The compositions of the reaction mixtures for $2 \mathrm{ml}$ of enzyme sample for the different enzymes are as follows:

\section{Polymethylgalacturonase (PMG)}

Five $\mathrm{ml}$ of one per cent pectin dissolved in

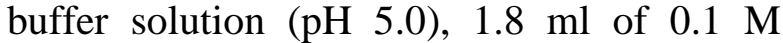
phosphate citrate buffer $(\mathrm{pH} 5.0)$ and $1.5 \mathrm{ml}$ of distilled water.

\section{Polygalacturonase (PG)}

Five $\mathrm{ml}$ of one per cent sodium polypectate dissolved in buffer solution ( $\mathrm{pH} 5.0), 1.8 \mathrm{ml}$ of $0.1 \mathrm{M}$ phosphate citrate buffer ( $\mathrm{pH}$ 5.0) and $1.5 \mathrm{ml}$ of distilled water.

\section{Cellulolytic enzymes (CX)}

Five $\mathrm{ml}$ of 1.2 per cent carboxymethyl cellulose (CMC) dissolved in $1.8 \mathrm{ml}$ of $0.1 \mathrm{M}$ phosphate citrate buffer solution ( $\mathrm{pH} \mathrm{5.0)}$ and $1.8 \mathrm{ml}$ of distilled water.

The enzyme activity was assessed by determining the loss in viscosity of the reaction mixture immediately at intervals of 10,30 and 120 minutes at $30^{\circ} \mathrm{C}$. Each treatment was replicated for three times.

The per cent enzyme activity was calculated by the following formula:

$\frac{V_{0}-V t}{V_{0}-V_{w}} \times 100$

Where,

$\mathrm{Vo}=$ The flow time at $0 \mathrm{~min}$

$\mathrm{Vt}=$ The flow time after 10/30/120 min

$\mathrm{Vw}=$ The flow time of distilled water.

\section{Results and Discussion}

Estimation of total protein, total sugar and total phenol, calcium and phosphorous from infected and healthy tissues

\section{Total protein, total sugar and phenol}

The results of total protein content in fruits inoculated with Colletotrichum dematium and control fruits at different periods are given in table 1 .

The results revealed that total protein content of inoculated papaya fruits with pathogen $(C$. dematium) was decreased by $1.40,1.25,1.01$, $0.91,0.70,0.63,0.58$ and 0.36 per cent at $1^{\text {st }}$, $2^{\text {nd }}, 3^{\text {rd }}, 4^{\text {th }}, 5^{\text {th }}, 6^{\text {th }}, 7^{\text {th }}$ and $8^{\text {th }}$ day after inoculation, respectively while in control fruit protein content was $1.80 \mathrm{mg} / \mathrm{g}$.

Least protein content $(0.36 \mathrm{mg} / \mathrm{g})$ was found after $8^{\text {th }}$ day of inoculation which was at par with $7^{\text {th }}$ day $(0.58 \mathrm{mg} / \mathrm{g})$ after inoculation. It was observed that protein content of papaya pulp decreased progressively as there is an increase in duration after inoculation with $C$. dematium as compared to control fruits (1.80 $\mathrm{mg} / \mathrm{g}$ ).

The results of total soluble sugar content in fruits inoculated with Colletotrichum dematium at different periods. The results revealed that TSS in inoculated papaya fruits with $C$. dematium progressively decreased by $10.08,9.21,7.59,6.20,5.63,3.93,3.71$ and 3.42 per cent at $1^{\text {st }}, 2^{\text {nd }}, 3^{\text {rd }}, 4^{\text {th }}, 5^{\text {th }}, 6^{\text {th }}, 7^{\text {th }}$ and $8^{\text {th }}$ day after inoculation, respectively while in control fruit TSS was 11.07 per cent. Lowest TSS content was found after $8^{\text {th }}$ day $(3.42 \%)$ of inoculation which was at par with $7^{\text {th }}$ day after inoculation $(3.71 \%)$.

It was observed that TSS of papaya pulp progressively decreased as there is an increase in duration after inoculation with $C$. dematium as compared to control fruits $(11.07 \%)$. 
The results of total phenol content in papaya fruits inoculated with $C$. dematium were compared with that of control (uninoculated) fruits at different periods. The data revealed that there was appreciable increase in phenol content up to $3^{\text {rd }}$ day after inoculation due to rapid accumulation and then there was gradual decrease in total phenol content in papaya fruits when inoculated with $C$. dematium at different periods.

Highest amount of total phenol content $(544 \mathrm{mg} / \mathrm{g})$ was observed on $3^{\text {rd }}$ day after inoculation followed by which was at par with $0.522,0.544$ and $0.495 \mathrm{mg} / \mathrm{g}$ on $2^{\text {nd }}(0.522$ $\mathrm{mg} / \mathrm{g})$ and $3^{\text {rd }}$ day $(0.516 \mathrm{mg} / \mathrm{g})$ of inoculation, respectively. After $4^{\text {th }}$ day of inoculation, there was gradual decrease in phenol content observed. Significantly lowest phenol content was recorded on $8^{\text {th }}$ day $(0.274$ $\mathrm{mg} / \mathrm{g})$.

Phenol accumulated in the fruits infected by pathogen which might be inactivate the enzymes of parasite or pathogens by forming poly phenol oxydase which in turn prevented further advancement of pathogen by limiting its source of nutrients. The significance of phenols in papaya fruit is to trigger the resistance.

\section{Ash, calcium and phosphorous content}

Ash, calcium and phosphorous content of papaya fruits inoculated with $C$. dematium were assayed and compared with that of control (uninoculated) fruits at different periods. The data presented in table 2 revealed that there was decrease in Ash, Calcium and phosphorous content in papaya fruits when inoculated with $C$. dematium at different period as compared to control.

Ash Content in fruits inoculated with Colletotrichum dematium at different periods are given in table 2 . The results revealed that Ash content of inoculated papaya fruits with
C. dematium decreased progressively (393.33, $386.67,377.33,355.67,337.67,304.33$, 273.00 and $263.33 \mathrm{mg} / 100 \mathrm{~g}$ ) as the duration after inoculation increased at $1^{\text {st }}, 2^{\text {nd }}, 3^{\text {rd }}, 4^{\text {th }}$, $5^{\text {th }}, 6^{\text {th }}, 7^{\text {th }}$ and $8^{\text {th }}$ day after inoculation, respectively while in control fruit ash content was $403.67 \mathrm{mg} / 100 \mathrm{~g}$.

The calcium content from papaya tissues inoculated with $C$. dematium was progressively reduced as per the duration. The results indicated that the calcium content was reduced at inoculation and it was gradually reduced at subsequent periods of incubation. The lowest calcium content was recorded on $8^{\text {th }}$ day of inoculation $(12.17 \mathrm{mg} / 100 \mathrm{ml})$ followed by $7^{\text {th }}$ day $(13.80 \mathrm{mg} / 100 \mathrm{ml})$.

The results revealed that calcium content of inoculated papaya fruits with $C$. dematium decreased by $18.75,18.02,17.42,16.43$, $15.53,14.90,13.80$ and $12.17 \mathrm{mg} / 100 \mathrm{~g}$ at $1^{\mathrm{st}}$, $2^{\text {nd }}, 3^{\text {rd }}, 4^{\text {th }}, 5^{\text {th }}, 6^{\text {th }}, 7^{\text {th }}$ and $8^{\text {th }}$ day after inoculation, respectively while in control fruit calcium content was $19.53 \mathrm{mg} / 100 \mathrm{~g}$.

The same trend of results was observed in phosphorous content. Changes in phosphorous content in papaya fruits inoculated with $C$. dematium were compared with that of control (uninoculated) fruits at different periods. The results revealed that phosphorous content of inoculated papaya fruits with $C$. dematium decreased by 14.07 , $12.80,11.60,9.37,9.27,7.73,5.17$ and 3.53 $\mathrm{mg} / 100 \mathrm{ml}$ at $1^{\text {st }}, 2^{\text {nd }}, 3^{\text {rd }}, 4^{\text {th }}, 5^{\text {th }}, 6^{\text {th }}, 7^{\text {th }}$ and $8^{\text {th }}$ day after inoculation, respectively.

While in control fruit phosphorous was 15.20 $\mathrm{mg} / 100 \mathrm{ml}$. Least phosphorous content (3.53 $\mathrm{mg} / 100 \mathrm{ml}$ ) was noted in $8^{\text {th }}$ day of inoculation followed by $5.17 \mathrm{mg} / 100 \mathrm{ml}$ on $7^{\text {th }}$ day after inoculation. Pathogens are responsible for reduction in biochemical content of papaya fruit which revealed that the fungi have utilized it as a substrate for development. 
Table.1 Total protein, sugar and phenol content in papaya fruits inoculated with Colletotrichum dematium

\begin{tabular}{|c|c|c|c|c|}
\hline $\begin{array}{c}\text { Sr. } \\
\text { No. }\end{array}$ & Treatments & $\begin{array}{c}\text { Protein } \\
(\mathbf{m g} / \mathbf{g})\end{array}$ & $\begin{array}{c}\text { Sugar } \\
(\boldsymbol{\%})\end{array}$ & $\begin{array}{c}\text { Phenol } \\
(\mathbf{m g} / \mathbf{g})\end{array}$ \\
\hline \hline 1 & $1^{\text {st }}$ day & 1.40 & 10.08 & 0.516 \\
\hline 2 & $2^{\text {nd }}$ day & 1.25 & 9.21 & 0.522 \\
\hline 3 & $3^{\text {rd }}$ day & 1.01 & 7.59 & 0.544 \\
\hline 4 & $4^{\text {th }}$ day & 0.91 & 6.20 & 0.495 \\
\hline 5 & $5^{\text {th }}$ day & 0.70 & 5.63 & 0.343 \\
\hline 6 & $6^{\text {th }}$ day & 0.63 & 3.93 & 0.322 \\
\hline 7 & $7^{\text {th }}$ day & 0.58 & 3.71 & 0.291 \\
\hline 8 & $8^{\text {th }}$ day & 0.36 & 3.42 & 0.274 \\
\hline 9 & Control & 1.80 & 11.07 & 0.442 \\
\hline \hline & S.Em \pm & $\mathbf{0 . 0 6 0}$ & $\mathbf{0 . 1 0 7}$ & $\mathbf{0 . 2 0 9}$ \\
\hline & C.D. at $\mathbf{5 \%}$ & $\mathbf{0 . 1 8 0}$ & $\mathbf{0 . 3 1 9}$ & $\mathbf{0 . 8 0 0}$ \\
\hline \hline & C.V. $(\%)$ & $\mathbf{3 . 8 2 9}$ & $\mathbf{2 . 7 4 9}$ & $\mathbf{2 . 1 1}$ \\
\hline
\end{tabular}

Table.2 Calcium and phosphorous content of papaya fruits inoculated with Colletotrichum dematium

\begin{tabular}{|c|c|c|c|c|}
\hline $\begin{array}{c}\text { Sr. } \\
\text { No. }\end{array}$ & Treatments & $\begin{array}{c}\text { Ash } \\
(\mathrm{mg} / 100 \mathrm{ml})\end{array}$ & $\begin{array}{c}\text { Calcium } \\
(\mathbf{m g} / \mathbf{1 0 0 m l})\end{array}$ & $\begin{array}{c}\text { Phosphorous } \\
(\mathbf{m g} / \mathbf{1 0 0 m l})\end{array}$ \\
\hline 1 & $1^{\text {st }}$ day & 393.33 & 18.75 & 14.07 \\
\hline 2 & $2^{\text {nd }}$ day & 386.67 & 18.02 & 12.80 \\
\hline 3 & $3^{\text {rd }}$ day & 377.33 & 17.42 & 11.60 \\
\hline 4 & $4^{\text {th }}$ day & 355.67 & 16.43 & 9.37 \\
\hline 5 & $5^{\text {th }}$ day & 337.67 & 15.53 & 9.27 \\
\hline 6 & $6^{\text {th }}$ day & 304.33 & 14.90 & 7.73 \\
\hline 7 & $7^{\text {th }}$ day & 273.00 & 13.80 & 5.17 \\
\hline 8 & $8^{\text {th }}$ day & 263.33 & 12.17 & 3.53 \\
\hline 9 & Control & 403.67 & 19.53 & 15.20 \\
\hline & S.Em \pm & 2.865 & $\mathbf{0 . 3 0 5}$ & $\mathbf{0 . 1 2 0}$ \\
\hline & C.D. at $\mathbf{5 \%}$ & 8.513 & $\mathbf{0 . 9 0 7}$ & $\mathbf{0 . 3 5 7}$ \\
\hline & C.V. $(\boldsymbol{\%})$ & 1.442 & $\mathbf{3 . 2 4 8}$ & $\mathbf{2 . 1 1 2}$ \\
\hline
\end{tabular}


Table.3 Impact of papaya fruit ripening on synthesis of cell wall degrading enzymes by $C$. dematium

\begin{tabular}{|c|c|c|c|c|c|c|c|c|c|c|c|c|}
\hline \multirow{4}{*}{ Stage } & \multicolumn{12}{|c|}{ Per cent reduction in viscosity } \\
\hline & \multicolumn{4}{|c|}{ Polygalacturonase } & \multicolumn{4}{|c|}{ Polymethylgalacturonase } & \multicolumn{4}{|c|}{ Cellulolytic enzymes } \\
\hline & \multicolumn{3}{|c|}{ Minutes } & \multirow{2}{*}{ Mean } & \multicolumn{3}{|c|}{ Minutes } & \multirow{2}{*}{ Mean } & \multicolumn{3}{|c|}{ Minutes } & \multirow{2}{*}{ Mean } \\
\hline & 10 & 30 & 120 & & 10 & 30 & 120 & & 10 & 30 & 120 & \\
\hline Semi-ripe & 19.13 & 23.24 & 31.85 & 24.94 & 14.09 & 22.09 & 30.30 & 22.16 & 1814.81 & 22.33 & 30.41 & 22.52 \\
\hline Ripe & 32.24 & 39.38 & 445.65 & 39.09 & 19.27 & 27.90 & 36.48 & 27.88 & 19.30 & 26.10 & 34.92 & 26.77 \\
\hline Healthy & 9.46 & 13.58 & 21.27 & 14.77 & 9.88 & 12.47 & 17.27 & 13.20 & 8.34 & 11.67 & 16.80 & 12.27 \\
\hline Mean & 20.28 & 25.60 & 32.93 & & 18.41 & 20.82 & 28.07 & & 14.15 & 19.90 & 27.37 & \\
\hline Source & \multicolumn{2}{|c|}{ S. Em. + } & \multicolumn{2}{|c|}{ C. D. } & \multicolumn{2}{|c|}{ S. Em. + } & \multicolumn{2}{|c|}{ C. D. } & \multicolumn{2}{|c|}{ S. Em. + } & \multicolumn{2}{|c|}{ C. D. } \\
\hline Stage $(S)$ & \multicolumn{2}{|c|}{0.47} & \multicolumn{2}{|c|}{1.86} & \multicolumn{2}{|c|}{1.54} & \multicolumn{2}{|c|}{6.17} & \multicolumn{2}{|c|}{$\begin{array}{c}0.138 \\
\end{array}$} & \multicolumn{2}{|c|}{0.391} \\
\hline Period (P) & \multicolumn{2}{|c|}{0.02} & \multicolumn{2}{|c|}{1.07} & \multicolumn{2}{|c|}{0.17} & \multicolumn{2}{|c|}{0.49} & \multicolumn{2}{|c|}{1.194} & \multicolumn{2}{|c|}{4.686} \\
\hline $\mathbf{S} \times \mathbf{P}$ & \multicolumn{2}{|c|}{0.04} & \multicolumn{2}{|c|}{0.12} & \multicolumn{2}{|c|}{0.30} & \multicolumn{2}{|c|}{0.86} & \multicolumn{2}{|c|}{ Sig. } & \multicolumn{2}{|c|}{ Sig. } \\
\hline C.V. \% & \multicolumn{4}{|c|}{1.56} & & 5. & & & & & & \\
\hline
\end{tabular}

$\mathrm{CD}$ at $5 \%$ 
Estimation of cell wall degrading enzymes on disease development

The activities of Polygalaturonase (PG), Polymethylgalacturonase (PMG) and Cellulolytic enzymes (CX) were studied at ripe and semi ripe fruit stage inoculated with C. dematium and healthy fruit. The enzymatic activities of PG, PMG and CX were higher in ripe fruits $(39.09,27.88$ and $26.77 \%)$ than in semi ripe ones $(24.94,22.16,22.52 \%)$, respectively.

The enzymatic activities of PG, PMG and CX were found to be increased with time. Highest reduction in viscosity was observed in PG in ripe fruit at 120 min with $39.09,27.88$ and 26.77 per cent respectively (Table 3 ).

The interaction effect between stage of fruit ripeness and period were found significant. The enzymatic activity (PG, PMG and CX) was lowest in healthy fruits as compared to inoculated fruits.

Results similar to the present investigation were reported by Patil and Pathak (1994). They found that activity of polygalacturonase (PG), polymethylgalacturonase (PMG) and cellulolytic enzymes (CX) were highest at all intervals $(10,30$ and $120 \mathrm{~min}$.) in ripe mango fruits compared to semi ripe fruits infected with Botryodiplodia theobromae and Rhizopus arrhizus.

The present results found similar to the result obtained by Agrawal and Agarwal (1982). According to them the phenolic metabolism of unripe papaya fruits inoculated with $C$. dematium was altered.

They reported that total phenol accumulated rapidly and remained in high concentrations for four days in tissues. Thereafter, total phenols markedly decreased in the virulent pathogen-host combinations. They concluded that significance of phenols in the resistance of papaya fruits to Colletotrichum spp. Majumdar and Pathak (1989) concluded that content of ascorbic acid, sugars and protein content was declined in the guava fruits infected by Botryodiplodia theobromae, Colletotrichum gloeosporioides and Pestalotiopsis versicolor.

Maximum decrease in protein content was observed due to infection of Colletotrichum gloeosporioides. Rathod and Chavan (2012) revealed that Post-harvest fungi depleted and reduced the pectin, sugar, ash, phosphorous, calcium and ascorbic acid content of papaya fruit infected with Colletotrichum gloeosporioides.

They recorded gradual reduction in calcium and phosphorous content $(11.5 \mathrm{mg} / 100 \mathrm{ml}$ and $8.4 \mathrm{mg} / 100 \mathrm{ml})$ as compare to control (16.0 and $9.1 \mathrm{mg} / 100 \mathrm{ml})$. Rajmane and Korekar (2014) reported that reducing sugar content of mango and papaya were found to be decreased due to some post-harvest fungi (Colletotrichum gloeosporioides, Botryodiplodia theobromae, Penicillium chrysogenum Aspergillus niger, Aspergillus flavus) as compare to control.

These differences may be due to deterioration caused by the fungi since fungi require some essential nutrients for growth and survival. Srivastava and Kumar et al., (2010a) reported that the nutrient value of vegetables decreased due to infection of Colletotrichum sp. infecting capsicum.

The reduction in protein, reducing sugar and non-reducing sugar was noted in infected capsicum by Colletotrichum sp.

Paull and Chen (1983) studied enzyme like pectinmethylesterase (PME), poly galacturonase (PG), xylanase, cellulase and proteinase activity related to respiration, ethylene evolution and changes in skin color of papaya fruit from harvest till to the start of 
fruit breakdown. The activity of PG declined to a level one-quarter of peak activity. Hossain et al., (1999) also studied the activities of peroxidase, polyphenol oxidase and catalase. They noted that the activity increased about five, two and three times in infected leaves of mango with Colletotrichum gloeosporioides as compared to those in healthy leaves, respectively. A close relationship exists between PG, PMG and CX of inoculated papaya at different stages which rise in respiration, ethylene evolution, and softening of tissues.

\section{Acknowledgement}

The authors are highly grateful to the Professor and Head, Department of Plant Pathology and Principal, B.A. College of Agriculture, Anand Agricultural University, Anand, for providing necessary facilities and other faculty members for guidance and moral support.

\section{References}

Agrawal, P. and Agarwal, G. P. 1982. Alteration in the phenols of papaya fruits infected by Colletotrichum spp. Proc. Indian Natn. Sci. Acad. 3: 422-426.

Bell, T. A., Etchells, J. L. and Jones, I. D. 1955. A method for testing cucumber salt stock brine for softening activity. U. S. Dept. Agr. Res. Serv. pp. 72-75.

Bray, H. G. and Thorpe, W. V. 1954. Analysis of phenolic compounds of interest in metabolism. Methods in Biochemistry Analysis. 1: 27-52.

Dubois, M., Gilles, K. A., Hamilton, J. K., Rebers, P. A. and Smith, F. 1956. Colorimetric Method for Determination of Sugars and
Related Substances. Anal. Chem. 28 (3): 350356.

Hossain, M. T., Alam, M. Z. and Absar, N. 1999. Changes in different nutrients and enzyme contents in mango leaves infected with Colletotrichum gloeosporioides. Indian Phytopath. 52(1): 75-76.

Krishna, K. L., Paridhavi, M. and Patel, J. A. 2008. Review on nutritional, medicinal and pharmacological properties of Papaya (Carica papaya), Natural product radiance. 7 (4): 364-373.

Majumdar, V. L. and Pathak, V. N. 1989. Biocontrol of postharvest diseases of Guava fruits by Trichoderma spp. Acta Bot. Indica. 23: 263-267.

Lowry, O. H., N. J. Rosebrough, Farr, A. L. and Randall, R. J. 1951. Protein Measurement with the Folin Phenol Reagent. J. Biol. Chem. 193:265-275.

Paull, R. E. and Chen, N. J. 1983. Postharvest variation in cell wall-degrading enzymes of papaya (Carica papaya L.) during fruit ripening. Plant Physiol. 72:382-385.

Rajmane S. D. and Korekar S. L. 2014. Biochemical changes (Reducing Sugar) in different mango and papaya fruits varieties. International Journal of Scientific and Research Publications. 4(3): 1-3.

Rathod, G. and Chavan, A. M. 2012. Status of biochemical content in papaya (Carica papaya $\mathrm{L}$.) after post-harvest pathogenesis by fungi. Current Botany. 3(3): 28-33.

Srivastava, A. and Kumar, S. 2013. Biochemical Changes in post harvested Allium cepa (Onion) and Capsicum annuum (Capsicum) under the influence of pathogens. IOSR Journal of Agriculture and Veterinary Science. 5(4):18-21.

Thamaraikannan, M. and Sengottuvel, C. 2012. Papaya cultivation and export, Facts for you, December-2012, pp. 21-24.

\section{How to cite this article:}

Prajapati, H.N., R.K. Patil and Shukla, Y.M. 2017. Studies on Biochemical Changes and Changes in Cell Wall Degrading Enzymes in Papaya Fruit Inoculated with Colletotrichum demetium. Int.J.Curr.Microbiol.App.Sci. 6(7): 1953-1961.

doi: https://doi.org/10.20546/ijcmas.2017.607.232 